\title{
Penerapan Model UTAUT 2 untuk Menjelaskan Minat dan Perilaku Penggunaan Mobile Banking
}

\author{
Ni Kadek Rahayu Nopiani ${ }^{1}$ \\ Fakultas Ekonomi dan Bisnis \\ Universitas Udayana, Indonesia
}

\author{
I Made Pande Dwiana Putra ${ }^{2}$ \\ Fakultas Ekonomi dan Bisnis \\ Universitas Udayana, Indonesia
}

\begin{abstract}
Surel : rahayuons@gmail.com
ABSTRAK

Tujuan penelitian ini adalah untuk mengetahui faktor-faktor yang memengaruhi minat dan perilaku penggunaan mobile banking dengan menerapkan model UTAUT2. Variabel yang digunakan dalam penelitian ini adalah ekspektasi kinerja, ekspektasi usaha, faktor sosial budaya, kondisi yang memfasilitasi, motivasi hedonis, nilai harga dan kebiasaan. Penelitian ini dilakukan di Kabupaten Badung. Penentuan sampel dilakukan dengan teknik accidental sampling. Pengumpulan data dilakukan dengan menyebarkan kuesioner secara online. Teknik analisis yang digunakan adalah regresi linier berganda. Penelitian ini menunjukkan bahwa minat penggunaan mobile banking dipengaruhi oleh ekspektasi kinerja, faktor sosial budaya, motivasi hedonis dan nilai harga. Hasil penelitian ini juga menunjukkan bahwa perilaku penggunaan mobile banking dipengaruhi oleh kondisi yang memfasilitasi, kebiasaan dan minat penggunaan.
\end{abstract}

Kata Kunci: UTAUT2; Minat Penggunaan Mobile banking; Perilaku Penggunaan Mobile banking.

\section{Application of the UTAUT 2 Model to Explain Mobile Banking Interest and Use Behavior}

\begin{abstract}
The purpose of this study was to determine the factors that influence the interest and behavior of using mobile banking by applying the UTAUT2 model. The variables used in this study are performance expectations, business expectations, socio-cultural factors, facilitating conditions, hedonic motivation, price values and habits. This research was conducted in Badung Regency. Determination of the sample is done by accidental sampling technique. Data was collected by distributing online questionnaires. The analysis technique used is multiple linear regression. This study shows that interest in using mobile banking is influenced by performance expectations, socio-cultural factors, hedonic motivation and price values. The results of this study also indicate that the behavior of using mobile banking is influenced by conditions that facilitate, habits and interest in use.
\end{abstract}

Keywords: $\quad$ UTAUT2; Interest in using Mobile banking; Mobile banking Usage Behavior.

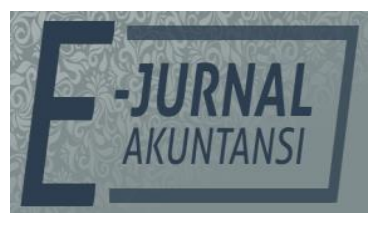

e-ISSN 2302-8556

Vol. 31 No. 10

Denpasar, Oktober 2021

Hal. 2569-2581

DOI:

10.24843/EJA.2021.v31.i10.p17

PENGUTIPAN:

Nopiani, N.K.R., \& Putra, I.M.P.D.P. (2021). Penerapan

Model UTAUT 2 untuk

Menjelaskan Minat dan Perilaku Penggunaan Mobile Banking. E-Jurnal Akuntansi, 31(10), 2569-2581

RIWAYAT ARTIKEL: Artikel Masuk: 29 Maret 2021 Artikel Diterima: 8 Juni 2021

Artikel dapat diakses : https://ojs.unud.ac.id/index.php/Akuntansi/index 


\section{PENDAHULUAN}

Mobile banking disediakan pihak bank untuk mendukung beragam transaksi guna memeroleh efektifitas dan efisiensi. Keunggulan lainnya yakni kerahasiaan user-id yang tidak dengan mudah diketahui oleh pihak lain (Pertiwi \& Aryanto, 2017). Penelitian (Putri \& Suardikha, 2019)mengemukakan bahwa kemunculan mobile banking di tengah-tengah masyarakat bertujuan untuk mengurangi tingkat pertumbuhan penggunaan uang tunai, dan meminimalisir kejahatan peredaran uang palsu. Berdasarkan hasil riset MARS Indonesia yang dimuat dalam Studi Pasar dan Perilaku Nasabah Mobile banking 2008/2008, setidaknya terdapat 3 alasan utama nasabah perbankan membutuhkan layanan m-banking, yaitu (1) praktis karena tidak perlu datang ke bank/ATM (46,5 persen), (2) transaksi menjadi lebih cepat (32,7 persen), dan (3) mempermudah untuk cek saldo melalui HP (17,8 persen). Ditinjau dari uraian tersebut, terdapat berbagai keuntungan melalui pemanfaatan mobile banking.

Hingga saat ini sudah banyak perusahaan-perusahaan yang ikut andil dalam menerbitkan uang elektronik (e-money), terdapat 51 perusahaan penyedia e-money (Lampiran 10). Dari 51 perusaahaan penerbit, tidak semuanya dapat ditemukan dibeberapa kota. Pada dasarnya para penerbit e-money menerbitkan dengan berbagai fasilitas penunjang yang hanya ada di kota-kota besar saja, karena kota besar lebih berpotensi dibandingkan dengan kota kecil. Dengan adanya alat pembayaran non tunai seperti $e$-money dalam sistem pembayaran oleh Bank Indonesia akan mampu mengoptimalkan daya beli masyarakat yang sekaligus akan berdampak pada meningkatnya perekonomian negara (Sofyan, 2015:4). Fitur yang sederhana membuat mobile banking melalui ponsel sangat mudah untuk dimengerti, semua instruksi diberikan secara mudah dan rinci sehingga efektif dari segi biaya. Sistem informasi mampu memberikan hal positif dalam penggunaannya ketika sistem informasi tersebut mempermudah seseorang dalam peningkatan kinerjanya (Widnyana \& Yadnyana, 2015).

Penelitian ini mencoba mengungkapkan faktor yang memengaruhi minat dan perilaku penggunaan mobile banking. Berbagai macam model penelitian telah dikembangkan untuk menjelaskan faktor-faktor yang memengaruhi minat dan penggunaan suatu sistem teknologi (Pertiwi \& Aryanto, 2017). Dalam penelitian ini, penulis menggunakan model Unified Theory of Acceptance and Use of Technology 2 (UTAUT2) yang dikembangkan oleh (Venkatesh et al., 2012). UTAUT dikembangkan (Venkatesh, et al. 2003) untuk mengetahui faktor yang mendorong seseorang menggunakan suatu sistem. Venkatesh, et al. (2003) menyatakan model ini terbukti berhasil 70 persen lebih dibandingkan model lainnya sehingga dirasa mampu menjelasakan minat dan perilaku penggunaan mobile banking di Kota Denpasar (Wulandari \& Yadnyana, 2016).

Model UTAUT2 menunjukkan bahwa niat untuk berperilaku (behavior intention) dan perilaku untuk menggunakan suatu teknologi (use behavior) dipengaruhi oleh ekspetasi kinerja (performance expectancy), ekspetasi usaha (effort expectancy), pengaruh sosial (social influence), kondisi yang memfasilitasi (facilitating conditions), motivasi hedonis (hedonic motivation), nilai harga (price value), dan kebiasaan (habit), memunculkan konstruk baru pada model teori ini karena perbedaan antar penelitian. Hasil analisis model UTAUT2 yang dikembangkan oleh Venkatesh et al., (2012) masih mempunyai beberapa 
kelemahan. Salah satunya instrumen konstruk faktor sosial berasal dari konstruk bahwa orang bertindak hanya karena dipengaruhi oleh orang yang ada disekitarnya, belum memasukkan konstruk tanggung jawabnya ke alam, tingkat spiritualitas individu, dan individu sebagai agen perubahan yang bersifat aktif.

Konstruk faktor sosial belum mampu menangkap konsep budaya organisasi yang menjadi dasar pembentukan dan berdirinya sebuah organisasi (Ardana \& Putra, 2018). UTAUT2 berbasis pada masalah perilaku manusia, diperkirakan penerapan model UTAUT2 dengan aplikasi, teknologi, dan pemakai pada industri yang sama dapat memberikan hasil yang berbeda karena adanya perbedaan budaya, baik itu pada tingkatan budaya organisasi dan budaya lokal atau budaya daerah(Pertiwi \& Aryanto, 2017). Chian (2012) meneliti bukti empiris dari UTAUT dalam hal faktor yang memengaruhi individu untuk mengadopsi mobile banking dan menunjukan hasil bahwa niat menggunaan mobile banking dipengaruhi oleh pengaruh sosial, ekspektasi biaya keuangan, ekspektasi kinerja, ekspektasi kredibilitas sedangkan variabel perilaku pengguna dipengaruhi oleh niat menggunaan dan kondisi pendukung.

Berbeda dengan penelitian sebelumnya yang memilih Kota Denpasar sebagai lokasi penelitian. Penelitian ini memilih Kabupaten Badung sebagai lokasi penelitian. Kabupaten Badung dipilih sebagai lokasi penelitian karena merupakan kabupaten dengan serapan dana terbesar kedua setelah Kota Denpasar (Wirawan \& Suardikha, 2016). Maka dari itu peneliti ingin mengetahui minat dan perilaku masyarakat Kabupaten Badung akan fasilitas mobile banking.

Ketika suatu sistem informasi memberikan kemudahan dalam peningkatan bekerja maka tandanya sistem informasi tersebut memberikan dampak positif dalam penggunaannya (Diana, 2018). Teori UTAUT menyatakan bahwa kemudahan penggunaan teknologi informasi akan menimbulkan perasaan minat dalam diri seseorang bahwa sistem itu mampu membantunya lebih efisien dalam melakukan pekerjaan. Penelitian (Iriani et al., 2014) membuktikan bahwa ekspektasi kinerja merupakan variabel yang memberikan pengaruh yang baik terhadap penerimaan aplikasi Sistem Informasi Pengelolaan Keuangan Daerah (SIPKD). Hal ini sejalan berdasarkan penelitian yang dilaksanakan oleh Davis, (1989), Taylor \& Todd, (1995) dan (Venkatesh \& Daves, 2000). Penelitian Venkatesh \& Daves (2000), (Venkatesh et al., 2012), (Wulandari \& Yadnyana, 2016), (Pertiwi \& Aryanto, 2017), dan (Mulyani, 2019) yang menunjukkan bahwa performance expectancy berpengaruh positif terhadap minat pengguaan sistem. Ekspektasi kinerja dalam konteks penelitian ini menyiratkan bahwa pengguna akan berekspektasi bahwa mobile banking berguna karena memungkinkan mereka untuk memperoleh kepraktisan dan kemudahan dalam sistem pembayaran.

$\mathrm{H}_{1}$ : Ekspektasi kinerja berpengaruh positif pada minat penggunaan mobile banking.

Berdasarkan teori UTAUT, ekspektasi usaha (Effort Expectancy) diformulasikan berdasarkan 3 konstruk pada model atau teori sebelumnya yaitu persepsi kemudahaan penggunaan (perceived easy of use-PEOU) dari model TAM, kompleksitas dari model of PC utilization (MPCU), dan kemudahan penggunaan dari teori difusi inovasi (IDT). Effort expectancy adalah tingkat kemudahan pengguna dalam penggunaan sistem informasi (Taylor \& Todd, 1995). Davis, (1989) mengidentifikasi bahwa penggunaan teknologi informasi dipengaruhi oleh 
kemudahan penggunaan. Tingkat kemudahan penggunaan terhadap suatu teknologi informasi akan menimbulkan perasaan dalam diri individu bahwa sistem itu mempunyai manfaat sehingga akan menimbulkan rasa nyaman penggunaannya (Venkatesh \& Daves, 2000). Auliya, (2018) menyimpulkan bahwa ekspektasi usaha memengaruhi minat penggunaan.

Ekpetasi usaha dalam penelitian ini menyiratkan bahwa pengguna akan berekspetasi bahwa mobile banking bermanfaat karena dapat mengurangi upaya (tenaga dan waktu) yang dikeluarkan oleh pengguna dibandingkan menggunakan alat pembayaran tunai atau uang kartal. Ekspektasi usaha berpengaruh signifikan positif terhadap minat pemanfaatan meskipun dengan pengalaman yang terbatas. Meyliana et al., (2012) menyimpulkan bahwa ekspektasi usaha memengaruhi minat penggunaan. Hasil tersebut konsisten dengan penelitian (Thompson et al., 1991).

$\mathrm{H}_{2}$ : Ekspektasi Usaha berpengaruh positif pada minat penggunaan mobile banking.

Theory Of Acceptance And Use Of Technologi (UTAUT) menjelaskan bahwa pengaruh sosial sebagai determinan langsung dari niat berperilaku direpresentasikan sebagai norma subjektif dalam TRA, TAM2, TPB/ DTPB dan CTAM-TPB, sosial faktor di MPCU, dan citra di IDT. Faktor sosial adalah tingkat kepercayaan seseorang terhadap orang lain yang meyakinkan dirinya untuk menggunakan suatu sistem yang baru. Hasil empiris penelitian yang dilakukan (Mulyani, 2019). Mulyani, (2019) membuktikan bahwa faktor sosial berpengaruh positif terhadap minat penggunaan suatu sistem. Penelitian Ariyanto merekonstruksi definisi dan pengukuran konstruk faktor sosial dari perspektif budaya organisasi dan tingkat spiritual dengan mengganti konstruk faktor sosial menjadi faktor sosial budaya. Budaya yang diadopsi dalam konstruk ini yaitu budaya masyarakat Bali, Tri Hita Karana (THK).

THK mengandung elemen parahyangan, palemahan, dan pawongan. Tujuan dari THK adalah mencapai kebahagiaan hidup melalui proses harmoni, keselarasan, keseimbangan, dan kebersamaan dalam berbagai konteks kehidupan (Pertiwi \& Aryanto, 2017). Hal ini berarti berarti bahwa lingkungan alam, lingkungan manusia atau masyarakat, dan lingkungan pola pikir/konsep/nilai yang berkembang dalam masyarakat akan dapat memengaruhi tujuan akhir yang akan dicapai oleh sistem tersebut.

$\mathrm{H}_{3}$ : Faktor Sosial Budaya berpengaruh positif pada minat penggunaan mobile banking.

Venkatesh et al., (2012) menambahkan konstruk motivasi hedonis ke dalam UTAUT2 untuk menangkap emosi kenikmatan, dengan alasan bahwa untuk sistem sukarela, motivasi hedonis akan lebih berpengaruh. Studi sebelumnya tentang UTAUT2 ditemukan motivasi hedonis memiliki pengaruh yang signifikan terhadap niat berperilaku konsumen mengadopsi mobile banking (Baptista \& Oliveira, 2016).

$\mathrm{H}_{4}$ : Faktor Motivasi Hedonis berpengaruh positif pada minat penggunaan mobile banking.

Teori UTAUT menjelaskan bahwa nilai harga (price value) berasal dari nilai yang dirasakan, yang sering dianggap sebagai indikator penting dalam memprediksi perilaku pembelian yang dapat memengaruhi keunggulan kompetitif perusahaan. Secara tradisional, definisi price value adalah trade off 
antara manfaat dan pengorbanan. Ketika manfaat yang dirasakan lebih besar dari biaya yang dikeluarkan, konsumen menunjukkan kesediaan untuk mengadopsi teknologi tertentu (Venkatesh et al., 2012). Hasil Penelitian Jung et al., (2016) menyimpulkan bahwa nilai harga berpengaruh positif pada pemanfaatan sistem jam pintar.

$\mathrm{H}_{5}$ : Faktor Nilai Harga berpengaruh positif pada minat penggunaan mobile banking.

Kondisi yang memfasilitasi dalam UTAUT memengaruhi penggunaan teknologi secara langsung. Konstruk kondisi yang memfasilitasi dibangun atas dasar tiga konstruk model teori sebelumnya yaitu, kontrol keperilakuan yang dipersepsikan dari TPB/Decomposed TPB, Combined-TAM-TPB, kondisi yang memfasilitasi dari MPCU dan kecocokan dari IDT. Semakin banyaknya fasilitas baik infrastruktur maupun sarana dan prasarana teknis lainnya yang disediakan organisasi untuk mendukung pemanfaatan sistem informasi maka kecenderungan seseorang untuk memanfaatkan sistem informasi akan semakin meningkat (Nugraha \& Yadnyana, 2018). Kondisi pendukung mencerminkan pengaruh sumber daya yang dibutuhkan seperti internet atau memori untuk smartphone dan hardware serta yang penting juga ialah pengetahuan dalam meningkatkan minat penggunaan terhadap teknologi. Perilaku tidak terjadi jika kondisi obyektif dalam lingkungan menghalanginya (Thompson et al., 1991). Penelitian ini sejalan dengan penelitian (Auliya, 2018).

$\mathrm{H}_{6}$ : Faktor Kondisi yang Memfasilitasi berpengaruh positif pada perilaku penggunaan mobile banking.

Kebiasaan adalah sejauh mana konsumen cenderung melakukan penggunaan teknologi atau penggunaan produk teknologi otomatis karena belajar. Kebiasaan terdiri dari tiga kriteria yaitu perilaku masa lalu, perilaku refleks, dan pengalaman individu (Ramdani et al, 2017). Penelitian Venkatesh et al, (2012) menunjukkan bahwa ada pengaruh yang signifikan dari kebiasaan konsumen pada penggunaan teknologi pribadi ketika mereka menghadapi lingkungan yang beragam dan selalu berubah. Hasil tersebut juga konsisten dengan penelitian Pertiwi \& Dodik (2017), Ramdhani et al. (2017), Sutanto et al. (2018), serta Auliya (2018).

$\mathrm{H}_{7}$ : Faktor Kebiasaan berpengaruh positif pada perilaku penggunaan mobile banking.

Teori UTAUT menjelaskan bahwa peran niat sebagai kriteria kunci dalam penelitian penerimaan penggunaan harus menyelidiki konstruksi potensial lainnya seperti perilaku harapan Warshaw \& Davis, (1985) atau kebiasaan Venkatesh et al., (2012) dalam jaringan monologis. Theory of Reasoned Action (TRA) menyatakan bahwa niat individu untuk tidak melakukan atau melakukan suatu perilaku merupakan penentu langsung dari tindakan atau perilaku. Individu akan melakukan suatu perilaku (behavior) bila memiliki keinginan atau niat (behavioral intention) untuk melakukannya. (Thompson et al., 1991) mengemukakan bahwa perilaku seseorang merupakan ekspresi dari keinginan atau minat seseorang (intention), dimana keinginan tersebut dipengaruhi oleh faktor-faktor sosial, perasaan (affect) dan konsekuensi-konsekuensi yang dirasakan (perceived consequences). Davis (1861) mengemukakan bahwa adanya manfaat yang dirasakan oleh pemakai sistem informasi akan meningkatkan minat mereka untuk 
menggunakan sistem informasi. Penelitian Pertiwi \& Aryanto, (2017) menunjukkan bahwa variabel minat penggunaan mobile banking berpengaruh positif signifikan pada perilaku penggunaan mobile banking.

$\mathrm{H}_{8}$ : Faktor Minat Penggunaan berpengaruh positif pada perilaku penggunaan mobile banking.

\section{METODE PENELITIAN}

Penelitian ini memilih Kabupaten Badung sebagai lokasi penelitian. Kabupaten Badung dipilih sebagai lokasi penelitian karena merupakan kabupaten dengan serapan dana terbesar kedua setelah Kota Denpasar (Wirawan \& Suardikha, 2016). Maka dari itu peneliti ingin mengetahui minat dan perilaku masyarakat Kabupaten Badung akan fasilitas mobile banking.

Populasi dalam penelitian ini adalah pengguna mobile banking di Kabupaten Badung. Teknik pengambilan sampel yang digunakan dalam penelitian ini adalah menggunakan metode nonprohability sampling dengan teknik accidental sampling. Teknik accidental sampling didasarkan pada kenyataan bahwa mereka kebetulan muncul, dan subyek dipilih sesuai dengan ketentuan atau persyaratan sampel dari populasi tertentu yaitu masyarakat Kabupaten Badung yang menggunakan layanan mobile banking. Maka perhitungan jumlah sampel (n) yang dapat diperoleh yaitu 99,99 atau dibulatkan sebesar 100 orang. Kelonggaran ketelitian, dalam penelitian ini peneliti mengambil nilai kelonggaran 10 persen atau level signifikansi sebesar 90 persen Dengan demikian, jumlah sampel dalam penelitian ini dapat mewakili jumlah populasi yang ada, yaitu minimal 100 orang.

Teknik analisis data yang digunakan adalah analisis regresi linier berganda. Analisis regresi linier berganda dilakukan dengan menggunakan program Satistical Package for Social Science (SPSS). Persamaan matematis untuk hubungan yang dihopetesiskan dapat dirumuskan sebagai berikut.

$\mathrm{Y}_{1}=\alpha+\beta_{1} \mathrm{X}_{1}+\beta_{2} \mathrm{X}_{2}+\beta_{3} \mathrm{X}_{3}+\beta_{4} \mathrm{X}_{5}+\beta_{5} \mathrm{X}_{6}+\varepsilon$

$Y_{2}=\alpha+\beta_{6} X_{4}+\beta_{7} X_{7}+\beta_{8} Y_{1}+\varepsilon$

Keterangan:

$\mathrm{Y}_{1}$ : Minat penggunaan mobile banking

$\mathrm{Y}_{2}$ : Perilaku penggunaan mobile banking

$\mathrm{X}_{1}$ : Ekspektasi kinerja

$\mathrm{X}_{2}$ : Ekspektasi usaha

$\mathrm{X}_{3}$ : Faktor sosial budaya

$\mathrm{X}_{4}$ : Kondisi yang memfasilitasi

$\mathrm{X}_{5}$ : Motivasi hedonis

$\mathrm{X}_{6}$ : Nilai harga

$\mathrm{X}_{7}:$ Kebiasaan

a : Konstanta

$\beta$ : Koefisien regresi

$\varepsilon$ : Standar error

\section{HASIL DAN PEMBAHASAN}

Statistik deskriptif digunakan untuk memberikan gambaran dari suatu data yang dilihat dari jumlah sampel, nilai minimum, nilai maksimum, nilai rata-rata (mean) dan devisiasi standar (std. devitiation) dari masing-masing variabel dalam 
penelitian tanpa adanya maksud untuk menarik kesimpulan. Hasil dari statistik deskriptif dapat dilihat pada Tabel 1, sebagai berikut.

Tabel 1. Hasil Statistik Deskriptif

\begin{tabular}{llllll}
\hline Variabel & $\mathrm{N}$ & Minimum & Maximum & Mean & $\begin{array}{l}\text { Std. } \\
\text { Devitiation }\end{array}$ \\
\hline Ekspektasi Kinerja & 105 & 18 & 25 & 22,22 & 2,253 \\
Ekspektasi Usaha & 105 & 10 & 15 & 13,38 & 1,424 \\
$\begin{array}{l}\text { Pengaruh Sosial } \\
\text { Motivasi Hedonis }\end{array}$ & 105 & 12 & 30 & 21,97 & 4,421 \\
Nilai Harga & 105 & 10 & 15 & 13,22 & 1,387 \\
$\begin{array}{l}\text { Kondisi } \\
\text { Memfasilitasi }\end{array}$ & 105 & 9 & 15 & 12,82 & 1,486 \\
$\begin{array}{l}\text { Kebiasaan yang } \\
\text { Minat penggunaan }\end{array}$ & 105 & 3 & 15 & 12,31 & 1,649 \\
$\begin{array}{l}\text { Mobile banking } \\
\text { Perilaku Penggunaan }\end{array}$ & 105 & 7 & 15 & 12,76 & 1,773 \\
Mobile banking & 105 & 8 & 10 & 8,31 & 1,303 \\
\hline
\end{tabular}

Sumber: Data Penelitian, 2021

Variabel ekspektasi kinerja $\left(X_{1}\right)$ memiliki nilai rata-rata (mean) sebesar 22,22. Nilai standar deviasi ekspektasi kinerja adalah sebesar 2,253. Nilai ini lebih rendah dibandingkan nilai rata-rata. Hal ini menunjukkan bahwa sebaran data berupa jawaban responden pada butir-butir pernyataan ekspektasi kinerja sudah merata, atau rentang data satu dengan yang lainnya tidak tergolong tinggi. Variabel ekspektasi usaha $\left(X_{2}\right)$ memiliki nilai rata-rata (mean) sebesar 13,38. Nilai standar deviasi ekspektasi usaha sebesar 1,424. Nilai ini lebih rendah dibandingkan nilai rata-rata. Hal ini menunjukkan bahwa sebaran data berupa jawaban responden pada butir-butir pernyataan ekspektasi usaha sudah merata, atau rentang data satu dengan yang lainnya tidak tergolong tinggi.

Variabel pengaruh sosial $\left(X_{3}\right)$ memiliki nilai rata-rata (mean) sebesar 21,97. Nilai standar deviasi pengaruh sosial sebesar 4,421. Nilai ini lebih rendah dibandingkan nilai rata-rata. Hal ini menunjukkan bahwa sebaran data berupa jawaban responden pada butir-butir pernyataan pengaruh sosial sudah merata, atau rentang data satu dengan yang lainnya tidak tergolong tinggi. Variabel motivasi hedonis $\left(\mathrm{X}_{4}\right)$ memiliki nilai rata-rata (mean) sebesar 13,22. Nilai standar deviasi motivasi hedonis sebesar 1,387. Nilai ini lebih rendah dibandingkan nilai rata-rata. Hal ini menunjukkan bahwa sebaran data berupa jawaban responden pada butir-butir pertanyaan motivasi hedonis sudah merata, atau rentang data satu dengan yang lainnya tidak tergolong tinggi.

Variabel nilai harga $\left(X_{5}\right)$ memiliki nilai rata-rata (mean) sebesar 12,82 . Nilai standar deviasi nilai harga sebesar 1,486. Nilai ini lebih rendah dibandingkan nilai rata-rata. Hal ini menunjukkan bahwa sebaran data berupa jawaban responden pada butir-butir pertanyaan nilai harga sudah merata, atau rentang data satu dengan yang lainnya tidak tergolong tinggi. Variabel kondisi yang memfasilitasi $\left(\mathrm{X}_{6}\right)$ memiliki nilai rata-rata (mean) sebesar 12,31. Nilai standar deviasi kondisi yang memfasilitasi sebesar 1,649. Nilai ini lebih rendah dibandingkan nilai ratarata. Hal ini menunjukkan bahwa sebaran data berupa jawaban responden pada butir-butir pertanyaan kondisi yang memfasilitasi sudah merata, atau rentang data satu dengan yang lainnya tidak tergolong tinggi. Variabel kebiasaan $\left(X_{7}\right)$ 
memiliki nilai rata-rata (mean) sebesar 12,76. Nilai standar deviasi kebiasaan sebesar 1,773. Nilai ini lebih rendah dibandingkan nilai rata-rata. Hal ini menunjukkan bahwa sebaran data berupa jawaban responden pada butir-butir pertanyaan kebiasaan sudah merata, atau rentang data satu dengan yang lainnya tidak tergolong tinggi.

Variabel minat penggunaan mobile banking $\left(\mathrm{Y}_{1}\right)$ memiliki nilai rata-rata (mean) sebesar 8,31. Nilai standar deviasi minat penggunaan mobile banking sebesar 1,303. Nilai ini lebih rendah dibandingkan nilai rata-rata. Hal ini menunjukkan bahwa sebaran data berupa jawaban responden pada butir-butir pertanyaan minat penggunaan mobile banking sudah merata, atau rentang data satu dengan yang lainnya tidak tergolong tinggi. Variabel perilaku penggunaan mobile banking $\left(\mathrm{Y}_{2}\right)$ memiliki nilai rata-rata (mean) sebesar 12,59. Nilai standar deviasi perilaku penggunaan mobile banking sebesar 1,874. Nilai ini lebih rendah dibandingkan nilai rata-rata. Hal ini menunjukkan bahwa sebaran data berupa jawaban responden pada butir-butir pertanyaan perilaku penggunaan mobile banking sudah merata, atau rentang data satu dengan yang lainnya tidak tergolong tinggi. Hasil analisis regresi linier berganda pada penelitian ini disajikan dalam Tabel 2, dan Tabel 3, sebagai berikut.

Tabel 2. Hasil Analisis Regresi Linier Berganda Persamaan 1

\begin{tabular}{|c|c|c|c|c|c|}
\hline \multirow[t]{2}{*}{ Model } & \multicolumn{2}{|c|}{$\begin{array}{l}\text { Unstandardized } \\
\text { Coefficients }\end{array}$} & \multicolumn{2}{|c|}{$\begin{array}{l}\text { Standardized } \\
\text { Coefficients }\end{array}$} & \multirow[b]{2}{*}{ Sig. } \\
\hline & $\mathrm{B}$ & Std. Error & Beta & $\mathrm{T}$ & \\
\hline (Constant) & $-0,219$ & 0,275 & & $-0,798$ & 0,427 \\
\hline Ekspektasi Kinerja & 0,080 & 0,020 & 0,196 & 3,930 & 0,000 \\
\hline Ekspektasi Usaha & 0,025 & 0,035 & 0,038 & 0,711 & 0,479 \\
\hline Pengaruh Sosial & 0,028 & 0,006 & 0,134 & 4,348 & 0,000 \\
\hline Motivasi Hedonis & 0,109 & 0,027 & 0,165 & 4,049 & 0,000 \\
\hline Nilai Harga & 0,370 & 0,027 & 0,597 & 13,744 & 0,000 \\
\hline \multicolumn{6}{|c|}{ Dependen Variabel : Minat penggunaan Mobile banking } \\
\hline R Square & \multicolumn{5}{|c|}{0,952} \\
\hline Adjusted $R$ Square & \multicolumn{5}{|l|}{0,921} \\
\hline F Statistik & \multicolumn{5}{|c|}{242,513} \\
\hline Signifikansi Uji F & \multicolumn{5}{|l|}{0,000} \\
\hline
\end{tabular}

Sumber: Data Penelitian, 2021

Tabel 2, menunjukkan bahwa variabel ekspektasi kinerja memiliki nilai signifikansi sebesar 0,000 yang lebih kecil dari taraf signifikansi sebesar 0,05 dengan $\beta_{1}$ bernilai positif sebesar 0,080 yang berarti bahwa $\mathrm{H}_{1}$ penelitian ini diterima. Hal ini berarti bahwa secara parsial ekspektasi kinerja berpengaruh positif pada minat penggunaan mobile banking.

Hipotesis pertama $\left(\mathrm{H}_{1}\right)$ yaitu ekspektasi kinerja berpengaruh positif pada minat penggunaan mobile banking diterima, penelitian ini sejalan dengan penelitian Pertiwi \& Aryanto (2019) yang menyatakan bahwa ekspektasi kinerja berpengaruh positif pada minat penggunaan mobile banking di Kota Denpasar. Ekspektasi kinerja yang dimaksud dalam penelitian ini berhubungan dengan waktu, kemudahan, kualitas output, dan efektivitas individu dalam penggunaan mobile banking. Menurut Venkatesh et al. (2003) ekspektasi kinerja merupakan variabel prediksi yang tangguh dari pemanfaatan sistem informasi. Hasil penelitian yang positif menjelaskan bahwa nasabah di Kabupaten Badung merasakan penggunaan 
mobile banking dapat membantu menyelesaikan pekerjaan mereka lebih cepat sehingga dapat meningkatkan produktivitasnya. Hasil penelitian ini juga konsisten dengan penelitian yang dilakukan oleh (Taylor \& Todd, 1995), (Venkatesh, 2000), dan (Pertiwi \& Aryanto, 2017).

Tabel 2, menunjukkan bahwa variabel ekspektasi usaha memiliki nilai signifikansi variabel sebesar 0,479 yang lebih besar dari taraf signifikansi sebesar 0,05 dengan $\beta_{2}$ bernilai positif sebesar 0,025 yang berarti bahwa $\mathrm{H}_{2}$ penelitian ini ditolak. Hal ini berarti bahwa secara parsial ekspektasi usaha tidak berpengaruh pada minat penggunaan mobile banking. Hipotesis kedua $\left(\mathrm{H}_{2}\right)$ yaitu ekspektasi usaha berpengaruh positif pada minat penggunaan mobile banking ditolak. Hasil penelitian ini juga didukung oleh hasil penelitian (Putri \& Suardikha, 2019) Ekspektasi usaha yang dimaksud dalam penelitian ini berkaitan dengan pemanfaatan sistem informasi yang dapat memudahkan seseorang dalam pekerjaannya. Tabel 2, menunjukkan bahwa variabel pengaruh sosial memiliki nilai signifikansi variabel sebesar 0,000 yang lebih kecil dari taraf signifikansi sebesar 0,05 dengan $\beta_{3}$ bernilai positif sebesar 0,028 yang berarti bahwa $\mathrm{H}_{3}$ penelitian ini diterima. Hal ini berarti bahwa secara parsial pengaruh sosial berpengaruh positif pada minat penggunaan mobile banking.

Hipotesis ketiga $\left(\mathrm{H}_{3}\right)$ yaitu pengaruh factor social budaya berpengaruh positif pada minat penggunaan mobile banking diterima. Faktor sosial yang dimaksud dalam penelitian ini berhubungan dengan pengaruh sosial dan status sosial individu. Moore dan Benbasat (1991) menyatakan bahwa penggunaan sistem informasi mampu meningkatkan image seseorang pada lingkungan sosial tertentu. Hal ini menunjukkan semakin tinggi pengaruh sosial pengguna maka semakin tinggi pula minat penggunaan mobile banking. Hasil penelitian ini konsisten dengan penelitian yang dilakukan oleh Wulandari \& Yadnyana (2016), (Putri \& Suardikha, 2019).

Tabel 2, menunjukkan bahwa variabel motivasi hedonis memiliki nilai signifikansi variabel sebesar 0,000 yang lebih kecil dari taraf signifikansi sebesar 0,05 dengan $\beta_{4}$ bernilai positif sebesar 0,109 yang berarti bahwa $\mathrm{H}_{4}$ penelitian ini diterima. Hal ini berarti bahwa secara parsial motivasi hedonis berpengaruh positif pada minat penggunaan mobile banking.

Hipotesis keempat $\left(\mathrm{H}_{4}\right)$ yaitu motivasi hedonis berpengaruh positif pada minat penggunaan mobile banking diterima. Hasil penelitian ini konsisten dengan penelitian yang dilakukan oleh Pertiwi \& Aryanto (2017). Motivasi hedonis didefinisikan sebagai hal menyenangkan atau kesenangan yang berasal dari penggunaan teknologi (Brown \& Venkatesh, 2005) Hal ini menunjukkan semakin tinggi motivasi hedonis pengguna maka semakin tinggi pula minat penggunaan mobile banking.

Tabel 2, menunjukkan bahwa variabel nilai harga memiliki nilai signifikansi variabel sebesar 0,000 yang lebih kecil dari taraf signifikansi sebesar 0,05 dengan $\beta 5$ bernilai positif sebesar 0,370 yang berarti bahwa $\mathrm{H}_{5}$ penelitian ini diterima. Hal ini berarti bahwa secara parsial nilai harga berpengaruh positif pada minat penggunaan mobile banking. Hipotesis kelima $\left(\mathrm{H}_{5}\right)$ yaitu nilai harga berpengaruh positif pada minat penggunaan mobile banking diterima. Nilai harga merupakan persepsi kesenjangan antara manfaat penggunaan suatu teknologi dengan biaya yang dikeluarkan untuk menggunakannya. Biaya penggunaan mobile banking 
terbilang murah jika dibandingkan dengan manfaat yang diperoleh. Hal ini menunjukkan pengguna merasakan manfaat yang lebih besar daripada beban biaya yang dikeluarkan. Semakin rendah biaya penggunaan maka semakin tinggi minat penggunaan mobile banking. Hasil penelitian ini konsisten dengan penelitian yang dilakukan oleh (Putri \& Suardikha, 2019).

Hasil uji kelayakan model (Uji F) yang disajikan dalam Tabel 2,

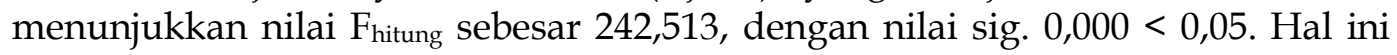
berarti bahwa ada pengaruh signifikan dari variabel ekspektasi kinerja, ekspektasi usaha, pengaruh sosial, motivasi hedonis dan nilai harga secara simultan terhadap minat penggunaan mobile banking. Dengan kata lain model regresi layak untuk digunakan.

Hasil uji koefisien determinasi dengan Adjusted $\mathrm{R}^{2}$ yang disajikan dalam Tabel 2, menunjukkan besarnya pengaruh variabel bebas terhadap variabel terikat adalah sebesar 0,925. Nilai ini mempunyai arti bahwa sebesar 92,5 persen variasi minat penggunaan mobile banking dipengaruhi oleh variasi ekspektasi kinerja, ekspektasi usaha, pengaruh sosial, motivasi hedonis dan nilai harga; sedangkan sisanya sebesar 7,5 persen djelaskan oleh faktor lain yang tidak dimasukkan ke dalam model.

Tabel 3. Hasil Analisis Regresi Linier Berganda Persamaan 2

\begin{tabular}{|c|c|c|c|c|c|}
\hline \multirow[t]{2}{*}{ Model } & \multicolumn{2}{|c|}{$\begin{array}{l}\text { Unstandardized } \\
\text { Coefficients }\end{array}$} & \multicolumn{2}{|l|}{$\begin{array}{l}\text { Standardized } \\
\text { Coefficients }\end{array}$} & \multirow[b]{2}{*}{ Sig. } \\
\hline & $\mathrm{B}$ & Std. Error & Beta & $\mathrm{T}$ & \\
\hline (Constant) & 0,453 & 0,270 & & 1,682 & 0,096 \\
\hline Kondisi yang Memfasilitasi & 0,156 & 0,020 & 0,178 & 7,924 & 0,000 \\
\hline Kebiasaan & 0,563 & 0,023 & 0,690 & 24,283 & 0,000 \\
\hline $\begin{array}{l}\text { Minat penggunaan Mobile } \\
\text { banking }\end{array}$ & $e_{0,362}$ & 0,043 & 0,230 & 8,403 & 0,000 \\
\hline \multicolumn{6}{|c|}{ Dependen Variabel: Perilaku Penggunaan Mobile banking } \\
\hline R Square & 0,965 & & & & \\
\hline Adjusted $R$ Square & 0,964 & & & & \\
\hline F Statistik & 935,105 & & & & \\
\hline Signifikansi Uji F & 0,000 & & & & \\
\hline
\end{tabular}

Sumber: Data Penelitian, 2021

Tabel 3, menunjukkan bahwa variabel kondisi yang memfasilitasi memiliki nilai signifikansi sebesar 0,000 yang lebih kecil dari taraf signifikansi sebesar 0,05 dengan $\beta 6$ bernilai positif sebesar 0,156 yang berarti bahwa $\mathrm{H}_{6}$ penelitian ini diterima. Hal ini berarti bahwa secara parsial kondisi yang memfasilitasi berpengaruh positif pada perilaku penggunaan mobile banking.

Hipotesis keenam $\left(\mathrm{H}_{6}\right)$ yaitu kondisi yang memfasilitasi berpengaruh positif pada perilaku penggunaan mobile banking diterima. Kondisi yang memfasilitasi dalam penelitian ini berhubungan dengan dukungan organisasi serta infrastruktur teknis yang tersedia untuk penggunaan suatu sistem. Hasil yang diperoleh dalam penelitian ini memiliki makna bahwa kondisi pendukung yang baik akan meningkatkan minat penggunaan mobile banking. Hal ini menunjukkan semakin tinggi kondisi yang memfasilitasi pengguna maka semakin tinggi pula perilaku penggunaan mobile banking. Hasil penelitian ini konsisten dengan penelitian yang dilakukan oleh (Nugraha \& Yadnyana, 2018). 
Tabel 3, menunjukkan bahwa variabel kebiasaan memiliki nilai signifikansi variabel sebesar 0,000 yang lebih kecil dari taraf signifikansi sebesar 0,05 dengan $\beta 7$ bernilai positif sebesar 0,563 yang berarti bahwa $\mathrm{H}_{7}$ penelitian ini diterima. Hal ini berarti bahwa secara parsial kebiasaan berpengaruh positif pada perilaku penggunaan mobile banking.

Hipotesis ketujuh $\left(\mathrm{H}_{7}\right)$ yaitu kebiasaan berpengaruh positif pada perilaku penggunaan mobile banking diterima. Hasil penelitian ini konsisten dengan penelitian yang dilakukan oleh (Pertiwi \& Aryanto, 2017), (Putri \& Suardikha, 2019), dan (Venkatesh et al., 2012). Kebiasaan didefinisikan sebagai sejauh mana seseorang cenderung untuk berperilaku secara otomatis karena pembelajaran sebelumnya. Hal ini menunjukkan semakin tinggi kebiasaan pengguna maka semakin tinggi pula perilaku penggunaan mobile banking.

Tabel 3, menunjukkan bahwa variabel minat penggunaan mobile banking memiliki nilai signifikansi variabel sebesar 0,000 yang lebih kecil dari taraf signifikansi sebesar 0,05 dengan $\beta 8$ bernilai positif sebesar 0,362 yang berarti bahwa $\mathrm{H}_{8}$ penelitian ini diterima. Hal ini berarti bahwa secara parsial minat penggunaan mobile banking berpengaruh positif pada perilaku penggunaan mobile banking. Hipotesis kedelapan $\left(\mathrm{H}_{8}\right)$ yaitu minat penggunaan berpengaruh positif pada perilaku penggunaan mobile banking diterima. Hasil penelitian ini sejalan dengan penelitian (Pertiwi \& Aryanto, 2017), (Putri \& Suardikha, 2019), (Venkatesh et al., 2012). Minat penggunaan mobile banking dalam penelitian ini berhubungan dengan minat seseorang dalam menggunakan suatu sistem secara terus menerus. Hal ini menunjukkan tanpa adanya minat untuk menggunakan mobile banking, maka nasabah bank di Kabupaten Badung tidak akan menggunakan layanan tersebut.

Hasil uji kelayakan model (Uji F) yang disajikan dalam Tabel 3 menunjukkan nilai $F_{\text {hitung }}$ sebesar 935,105, dengan nilai sig. 0,000 < 0,05. Hal ini berarti bahwa terdapat pengaruh signifikan dari variabel kondisi yang memfasilitasi, kebiasaan dan minat penggunaan mobile banking secara simultan terhadap perilaku penggunaan mobile banking. Dengan kata lain model regresi layak untuk digunakan. Hasil uji koefisien determinasi dengan Adjusted $\mathrm{R}^{2}$ yang disajikan dalam Tabel 3, menunjukkan besarnya pengaruh variabel bebas terhadap variabel terikat adalah sebesar 0,965. Nilai ini mempunyai arti bahwa sebesar 96,5 persen variasi perilaku penggunaan mobile banking dipengaruhi oleh variasi kondisi yang memfasilitasi, kebiasaan dan minat penggunaan mobile banking; sedangkan sisanya sebesar 3,5 persen djelaskan oleh faktor lain yang tidak dimasukkan ke dalam model.

\section{SIMPULAN}

Hasil dari penelitian ini diharapkan dapat digunakan untuk memvalidasi kembali dan menguji keandalan dari model teori UTAUT2 yang diterapkan pada mobile banking, serta sebagai salah satu hasil studi empiris untuk memberikan pemahaman, gambaran, dan wawasan untuk menjelaskan minat dan perilaku penggunan mobile banking di Kabupaten Badung dengan menerapkan model UTAUT2. Pada penelitian ini terbukti bahwa variabel ekspektasi kinerja, ekspektasi usaha, pengaruh sosial, motivasi hedonis dan nilai harga berpengaruh terhadap minat penggunaan mobile banking, serta variabel kondisi yang 
memfasilitasi, kebiasaan dan minat penggunaan berpengaruh terhadap perilaku penggunaan mobile banking. Dapat diartikan bahwa semakin tinggi ekspektasi kinerja, ekspektasi usaha, pegaruh sosial, motivasi hedonis, nilai harga kondisi yang memfasilitasi, kebiasaan, minat atau kesenangan yang didapatkan serta trade off antara biaya dan maafaat yang diterima pengguna menggunakan mobile banking maka akan meningkatkan kepercayaan seseorang bahwa sistem tersebut memiliki manfaat yang besar di masa mendatang dan termotivasi untuk menggunakan sistem tersebut. Kebiasaan merupakan sebagai sejauh mana seseorang cenderung untuk berperilaku secara otomatis karena pembelajaran sebelumnya, kebiasaan ini membuat pengguna ketagihan (addicted), sehingga menggunakan suatu sistem yang manfaatnya sangat dirasakan sebagai sebuah keharusan untuk dilakukan.

Theory of Reasoned Action (TRA) menyatakan bahwa niat individu untuk tidak melakukan atau melakukan suatu perilaku merupakan penentu langsung dari tindakan atau perilaku. Individu akan melakukan suatu perilaku (behavior) bila memiliki keinginan atau niat (behavioral intention) untuk melakukannya. Hasil dari penelitian ini diharapkan mampu dijadikan referensi bagi perusahaan perbankan untuk meningkatkan kualitas pelayanan mobile banking, mengedukasi masyarakat mengenai layanan dan fitur-fitur yang terdapat dalam mobile banking yang penggunaannya dapat memberikan kemudahan, ketepatan, dan kecepatan dalam melakukan transaksi.

\section{REFERENSI}

Ardana, K. T. F., \& Putra, I. M. P. D. (2018). Pengaruh Penggunaan Sistem Informasi Akuntansi Dengan Konsep UTAUT Pada Kinerja Individual. EJurnal Akuntansi, 25(2), https://doi.org/10.24843/eja.2018.v25.i02.p18

Auliya, N. (2018). Penerapan Model Unified Theory of Acceptance and.

Baptista, G., \& Oliveira, T. (2016). A weight and a meta-analysis on mobile banking acceptance research. Computers in Human Behavior, 63, 480-489. https://doi.org/10.1016/j.chb.2016.05.074

Davis, F. D. (1989). Perceived usefulness, perceived ease of use, and user acceptance of information technology. MIS Quarterly: Management Information Systems, 13(3), 319-339. https://doi.org/10.2307/249008

Diana, N. (2018). Indonesia Skripsi Oleh : Nama: Nur Diana Fakultas Ekonomi Universitas Islam Indonesia Yogyakarta. Analisis Faktor-Faktor Yang Mempengaruhi Minat Penggunaan Electronic Money Di Indonesia, 155.

Iriani, S., Suyanto, M., \& Amborowati, A. (2014). Pengujian Sistem Informasi Pengelolaan Keuangan Daerah Berbasis Web Kabupaten Pacitan Dengan Menggunakan Unified Theory of Acceptance and Use of Technology UTAUT). Indonesian Journal on Networking and Security, 3(2).

Jung, Y., Kim, S., \& Choi, B. (2016). Consumer valuation of the wearables: The case of smartwatches. Computers in Human Behavior, 63(2016), 899-905. https://doi.org/10.1016/j.chb.2016.06.040

Mulyani, A. (2019). Analisis Penerimaan dan Penggunaan Teknologi Aplikasi Ojek Online Menggunakan Unified Theory of Acceptance and Use Technology. Jurnal Algoritma, 15(2). https:// doi.org/10.33364/algoritma/v.15-2.61

Nugraha, G. S., \& Yadnyana, K. (2018). Penerapan Model UTAUT dalam 
Menjelaskan Faktor Minat dan Penggunaan Sistem Informasi Manajemen Daerah. E-Jurnal Akuntansi, 24(2), 959-987. https://doi.org/10.24843/EJA.2018.v24.i02.p06

Pertiwi, N. W. D. M. Y., \& Aryanto, D. (2017). Penerapan Model Utaut2 Untuk Menjelaskan Minat Dan Perilaku Penggunaan Mobile banking Di Kota Denpasar. E-Jurnal Akuntansi, 18(2), 1369-1397.

Putri, N. K. R. D., \& Suardikha, I. M. S. (2019). Penerapan Model UTAUT 2 Untuk Menjelaskan Niat Dan Perilaku Penggunaan E-Money di kota denpasar. EJurnal Akuntansi Universitas Udayana, 30(2), 540-555.

Taylor, S., \& Todd, P. (1995). Decomposition and crossover effects in the theory of planned behavior: A study of consumer adoption intentions. International Journal of Research in Marketing, 12(2), 137-155. https:/ / doi.org/10.1016/01678116(94)00019-K

Thompson, R. L., Higgins, C. A., \& Howell, J. M. (1991). Personal computing: Toward a conceptual model of utilization. MIS Quarterly: Management Information Systems, 15(1), 125-142. https:/ / doi.org/10.2307/249443

Venkatesh; Viaswanath, \& Davis; Fred D. (2000). A Theoretical Extension of the Technology Acceptance Model: Four Longitudinal Field Studies. Management Science, 46(2), 186-204. https:/ / www.jstor.org/stable/pdf/2634758.pdf

Venkatesh, V., Brown, S. A., \& Hoehle, H. (2012). Understanding technology adoption in the household context: A comparison of seven theoretical models. ECIS 2012 - Proceedings of the 20th European Conference on Information Systems.

Warshaw, P. R., \& Davis, F. D. (1985). Disentangling behavioral intention and behavioral expectation. Journal of Experimental Social Psychology, 21(3), 213228. https://doi.org/10.1016/0022-1031(85)90017-4

Widnyana, I. I. D. G. P., \& Yadnyana, I. K. (2015). Implikasi Model Utaut Dalam Menjelaskan Faktor Niat Dan Penggunaan Sipkd Kabupaten Tabanan. Jurnal Akuntansi Universitas Udayana, 11(2), 2302-8556.

Wirawan, B. S., \& Suardikha, I. M. S. (2016). Faktor-Faktor Yang Mempengaruhi Kinerja Individual Pada Bank Perkreditan Rakyat Di Kabupaten Badung. EJurnal Akuntansi Universitas Udayana, 17(3), 2352-2383. https://ojs.unud.ac.id/index.php/Akuntansi/article/view/24557

Wulandari, N. P. A., \& Yadnyana, I. K. (2016). Penerapan Model Unified Theory of Acceptance and Use of Technology Di Kota Denpasar. E-Jurnal Akuntansi Universitas Udayana, 14(2), 1270-1297. 